\title{
SOCIAL PROTECTION FOR PEOPLE IN DEPENDENCY SITUATIONS IN SPAIN AND ROMANIA: SAME PHENOMENON, DIFFERENT MANAGEMENT
}

\author{
José Ángel Martínez LÓPEZ ${ }^{1}$, Mihaela RADUCEA ${ }^{2}$ \\ DOI: $10.35782 / J C P P .2019 .3 .01$
}

\begin{abstract}
All European countries face the challenge of protecting a growing number of people in dependency situations as a result of increased life expectancy and ageing rates. Each country's response is determined by its social welfare model. On the basis of the differentiating singularities of Spain and Romania, this article makes a comparative analysis of both social policies of assistance to dependent people between those two countries, as well as the public management of social protection for people in need of long-term support.
\end{abstract}

Key words: dependency; Romania; Spain; public management, long-term support.

\section{Introduction}

Protecting people in dependency situations is one of the main developed countries' social policy challenges. Progress in this social issue is contextualized by each country's specific conditions and is determined by its social welfare model. In this respect, such a progress is conditioned by factors of political, ideological and financial nature.

The place that this social policy occupies on the EU countries' agenda is getting more and more central as ageing has increased over the past few years. As a matter of a fact, the rate of population aged 65 and over in the EU reaches higher levels each year. In the EU-28, it stands at $19.2 \%$, slightly higher than that of Spain and Romania with $18.7 \%$ and $17.4 \%$, respectively (Eurostat, 2016a). Population ageing is a consequence of the increase of life expectancy in the last decades. In 2016, life expectancy in the EU-28 was 81.0 years (+7.7 years since 1980) (Eurostat, 2016b). Spain has a high life

\footnotetext{
${ }^{1} \mathrm{PhD}$, Professor of the University of Murcia, Spain; Email: jaml@um.es

2 Social Worker in the Refugee Program of the Spanish Red Cross Murcia, Spain; E-mail: mihaela@cruzroja.es
} 
expectancy of 83.5 years ( +8 years since 1980). Romania, on the other hand, has slightly lower values than Spain, of 75.3 years in 2016 (+6.1 since 1980). As a consequence of the life expectancy increase, the number of octogenarians is growing; such rate being 6\% in Spain and 4.2\% in Romania (Eurostat, 2016b).

Most European countries are developing their own programmes to protect people in dependency situations, even if there are significant disparities in the way they are being developed by each country. Nevertheless, they are facing the challenge of establishing a system that guarantees attention to the needs of those people who are in particularly vulnerable situations and thus require support not only to carry out essential daily life activities, but also to be able to fully exercise their rights as citizens.

Different dimensions allow us to classify each model. Among them, the most outstanding ones are: social protection coverage, public responsibility versus individual responsibility, market participation level, legal concept of right, development of specific regulations and the role played by families in social welfare redistribution. These dimensions have been selected following other studies that raise the need to establish common indicators to compare social protection models (Arriba and Moreno, 2009; Martínez-López, 2017; Zalakain, 2017).

Spain and Romania are very different in relation to their development of social policies as well as in their social welfare models and also in their GDP per inhabitant according to their purchasing power standard $(\mathrm{EU} 28=100)$, where Spain has 92 and Romania 63 (Eurostat, 2018).

However, we can identify many similarities such as, for example, the preponderant role of families in the protection of family members or territorial decentralization in relation to social care. In addition, both countries entered late in the European Union as a consequence of their non-democratic political regimes, although for very different reasons: Spain's democratic opening came after the end of the dictatorial regime and in the case of Romania, following the fall of the Berlin Wall.

In pursuing the main objective of this research study, we seek to know, from a comparative perspective, which is the system of protection for people in dependency situations in Spain and Romania. We also seek to know the differences and similarities between them with the aim of pointing so out the main facts that determined development of their protection systems and, thus, contributing to the clarification and theoretical foundation of their social protection models within a European context. To such end, the research study is carried out from a three-dimensional axis analysing the theoretical, legislative and management aspects of social policy in both countries.

A pluralistic methodology has been followed with regard to our study object. On one hand, the qualitative methodology has been used to analyse Spanish and Romanian legislation on assistance to people in dependency situations. On the other hand, we have approached to those data that are most relevant in relation to the public management of policies aimed at people in dependency situations implementing the quantitative methodology. 
In the first part of the article, a theoretical and legislative analysis of both countries is carried out. Thereafter, we outline those secondary data that are most relevant to this analysis and describe the characteristics of both social welfare systems in relation to people in dependency situations. At the end of this research study, we present our conclusions and contributions.

\section{Social Protection and Welfare States: Different responses to the same phenomenon}

The concept of Welfare State (hereafter WS) was built in a very complex context, after the end of the Great Devastation in Europe. Academics agree to define it as the process initiated at the end of the 19th century by which State assumed certain functions to provide collective welfare and social protection. According to Toussaint (2010), the WS configuration period was characterized by the confluence of four elements: a massive trend of private companies to come under public control ("nationalizations"); spread of social security systems; development of the Fordist system, what enhances industrialization; peace agreements between the labour movement and the capitalist system.

Such concept is based on two main components: a redistributive one, which aims at achieving social welfare, and a universal one. Both of them favoured the development of social citizenship. Generally speaking, the term WS refers to the set of directed interventions provided by State and aimed at granting minimum services so that people are protected through a social system. In the most developed countries, the WS is one of the most significant achievements as a consequence of its ability to protect citizens from poverty when they are at risk (illness, unemployment, old age, childhood, etc.) and to make a contribution towards the correction of social fractures (Del Pino and Rubio, 2016).

The specialized literature contains many classifications on social welfare systems made over the years. Such classifications have undergone changes depending on the moment and on the criteria implemented by each author, even within the same country. Among these classifications, the one undertaken by Esping-Andersen (1990) stands out for its importance. The mentioned author tries to classify WS models depending on whether State, markets or families bear certain responsibilities. After having initially distinguished the liberal, the conservative and the social democratic model, Esping-Andersen later, in his 2000 work, also included the familistic model.

Traditionally, Spanish, Portuguese, Greek and Italian WSs have been characterized by an intense familism (Esping-Andersen, 2000), where the State intervenes in social policy in those cases in which needs are not covered by the families and, in most of the cases, with their support. This type of familism_sometimes ignores that care has been and is provided mainly by women within homes. However, "the new care relations indicate the need to review the traditional role of women in families following their increased labour market participation and following, especially, the achievement of greater gender parity in the distribution of household and family tasks" (Martínez-López, 2017, p. 142). 
Furthermore, as a consequence of the increase in life expectancy and population ageing, attention to people in dependency situations is one of the most important social policies in developed countries. Even if the management of this new social phenomenon depends mainly on the economic possibilities of a given country, they do not represent the only conditioning factor, for it also depends on the social welfare model of the country. The impact of this new policy emphasizes the greater participation of the State in the redistribution of Social Welfare. Consequently, it responds to a present and future need in advanced societies: social protection of people in dependency situations.

At present, following the outbreak of the economic crisis, weakness of familistic WSs in regulating citizens' social welfare, has become evident. However, the attention to people in dependency situations is a present and future challenge that requires social regulation and protection regardless of the ideological or political point of view. Therefore, we previously try to classify the models of social welfare in Spain and Romania, in a first approach to dependency-oriented social policy.

\subsection{The familistic protective social model in Spain}

Those social rights which are embodied in the Spanish Constitution laid the foundations for the creation of the Spanish WS as a public and organized social protection system, which was aimed at all citizens, reaching a level at which charitable and welfare actions are bettered. The arrival of socialist governments in the $80 \mathrm{~s}$ and $90 \mathrm{~s}$ was followed by the adoption of a series of measures which contributed to the construction of the WS whose focus was particularly on health, pensions and education.

Following the outburst of the economic crisis, there was growing evidence of the weakness of the Spanish familistic system and of the way in which families continue to be a reference point in the protection of social difficulties. Family protection policies have been confined for years to the private sphere where the $\square$ male breadwinner $\square$ model has played a preeminent role in society. However, "family policy - even under the new denomination of policy for families - has recently recuperated presence in the political debate and has acquired to some extent a leading role in the agenda of the main political parties" (Salido and Moreno, 2007, p. 112).

The Spanish social welfare model is still conditioned by its defective implementation process, due to the fact that when in the 1980s such model was settled down, in most developed countries it began to be criticised. Throughout the majority of the developed countries, the WS is still in force, but "its economic significance and its social and political implications have been object of numerous criticisms, so that in recent decades its existence has been questioned" (Del Pino and Rubio, 2013, p. 23).

In Spain, the WS intervenes to guarantee those minimum public services that can be further developed thanks to private contribution. The most recognised public services according to the collective perception are: public health services, education, social security -especially in the form of pensions-, social services and other services aimed at people's welfare (protection policies for the unemployed, protection policies for dependent persons, etc.). However, social protection policies are highly conditioned by 
economic drift and their financial dependence on economic cycles, so that there are constant advances and regressions in relation to social rights.

\subsection{The Romanian Welfare State: A model in progress}

Romania's political, economic and social context is very different from the Spanish one, as well as from those of all Western European countries. Although there is academic consensus that Spain has a familistic WS, in the case of Romania there are many doubts as to how to define its model. In fact, ex-Soviet countries have often been excluded from studies on social welfare models. For this reason, it is necessary to explore in depth Romania's WS background and its evolution in order to be able to classify and identify it.

After a period of over forty years under the communist regime and with a social economy, Romania had to go through a period of transition to such a market economy that is representative of capitalist WSs. For the country, this meant a break with the then ruling economic policy, which was characterised by rigid political institutions and a very weak social architecture.

The fact that social policies were going through a process of research and reorganization, of observation of Western European models, makes it plausible that Romania's WS cannot be classified according to a fixed typology. That is to say, due to the country's historical, democratic, economic and social trajectory, it is impossible that Romania's WS could be defined on the basis of a single model.

According to Fenger's typology (2007), Romania is not within the former communist countries' model (Bulgaria, Croatia, Czech Republic, Hungary, Poland and Slovakia), being among those countries which are still developing towards mature WS, such as Georgia and Moldova. There is general agreement that European former communist countries' WSs bear a clearer resemblance to those of traditional European countries. Comparing their characteristics with Esping-Andsen's ideal models there seems to be a combination of features of both conservative and social-democratic models in these countries. There are no grounds to sustain the assumption that the liberal model is being established in the former Eastern European countries.

One of the latest classifications is the one provided by Neesham and Tache (2010). In such classification, there is a reference to the EU member States models; particularly, to the significant contrast with respect to the role of the State between old and new EU members. Neesham and Tache explain that no ex-Soviet new EU member State has opted for a pure social model. On the other hand, they consider that there is a clear differentiation between these countries which are classified in two groups: 1) Baltic States, Slovakia and two south-east European members, namely Bulgaria and Romania; 2) new member States, such as Czech Republic, Hungary, Poland and Slovenia.

As opposed to Fenger's classification, these authors sustain that Romania belongs to a group in which a more neo-liberal (Anglo-Saxon) social model has been established, while in the second group the adopted model resembles the continental one. They indicate that no post-communist country has adopted the Nordic model. They also point out the existence of disruptive factors in eastern countries, such as corruption, 
rent-seeking or anti-social behaviour that must be taken into account when conceptualizing each model.

Despite the above-mentioned differences, two general coincidences are identified. On one hand, it is possible to control the tendencies towards a more individualistic approach that took place after the conclusion of the socialist era; and, on the other hand, the impossibility of new EU members to provide a WS which enjoys the same level of development as that of wealthier members. Such impossibility cannot be overcome, no matter what their political attitude is, at least as they are at such an early stage (Neesham and Tache, 2010).

Almost three decades after the 1989 Revolution, Romania is in a continuous transition period; that being the reason why the structure and role of social policies are still in a process of redefinition and development.

\section{Methodology}

According to a mixed methods research, the used methodologies are both qualitative and quantitative. After analysing the state of the question, the dimensions of the research were established, namely the legislative one and the dimension related to social protection of people in dependency situations. Each of them includes several units of analysis. Concerning the legislative dimension, following units of analysis were established: legislative authorship, concept of dependency protection, normative development, dependency degrees and dependency attention benefits. As for the dimension related to social protection of people in dependency situations, following units of analysis have been used: coverage and attention to people in dependency situations management, responsibility for public management and support for those who provide informal attention. As follows (Chart 1) the dimensions and units of analysis are summarized.

Table 1. Dimensions and units of analysis

\begin{tabular}{|c|l|}
\hline & - Legislative authorship \\
1. Legislative dimension & - Concept of dependency protection \\
& - Normative development \\
& - Dependency degrees \\
& - Dependency attention benefits \\
\hline 2. Dimension of social & - Coverage and Attention to people in dependency \\
protection for people in & situations management \\
dependency situations & - Responsibility in public management \\
& - support to Informal attention providers \\
\hline
\end{tabular}

Source: Own elaboration

The study of these variables, which is initially developed on the basis of the theoretical analysis of the characteristics of the WS in Spain and Romania, gives evidence of the legislative advances in the field of dependency in both countries and allows to know how social policy is currently being implemented. 


\section{Legislative evolution of attention to people in dependency situations in Spain and Romania}

\subsection{Social protection in relation to dependency in Spain}

In 2006, Spain passed Law 39/2006, of 14 December, on the Promotion of Personal Autonomy and Attention to people in dependency situations (hereinafter, LPAAD). One of the most important new characteristics of such Law is that the subjective right to receive care is granted to citizens (Article 1). Furthermore, social protection to people in such situation is provided within a new framework, established thanks to the creation of the System of Autonomy and Attention to Dependency (hereinafter, $\mathrm{SAAD})$, that differs from the existing one, which regarded elderly or disabled people. This new system is based on the principles of universality, equality and public character. This organizational and management structure has the objective of allowing people in dependency situations to be attended conveniently by means of the provision of services and/or economic benefits.

However, there was evidence of the difficulties faced throughout this period. Such difficulties have their origin in the very configuration of the social welfare model, which is characterised by the insufficient involvement of State, which was compensated by that support provided by families. This situation is not unique to Spain but to all European countries whose system of dependency undergoes the process of being defined.

Arriba and Moreno (2009) distinguish between formalised and universalist protection systems of those countries, which are characteristic of social-democratic welfare models (quality of employment, high female labour participation, relatively low level of informal care, scarce resources for undocumented immigration for the provision of care, etc.), as opposed to the model that seems to prevail in the countries, where the Mediterranean model has been consolidated (precarious employment, central role of irregular immigration in informal care schemes, greater difficulty for women to enter the labour market, etc.). (p. 26).

In Spain, there have been numerous regulatory changes regarding attention to people in dependency situations. Such changes were linked to the economic crisis and the initial model has been reconfigured as a result of them. Therefore, the identification of the proper characteristics of the model requires an approach to legislative changes and the implementation of the Law.

The LPAAD has focused too much on informal attention and economic benefits. The law itself "empowers relatives to be the main providers by means of direct monetary transfers in the form of monthly salaries" (Martínez-Buján, 2011, p. 119). In addition, such a structure that manages dependency relying heavily on the informal work of women as care providers can produce pernicious effects, since it evidences the continuation both of the 'male breadwinner' model and opportunities inequality, especially in relation to the development of women and their vital projects; so that a gender inequality model is perpetuated in the productive/reproductive market and in public/private spaces (Martínez-López, Frutos and Solano, 2017, p. 111). 
Since April 1, 2019, the LAAPD has a special agreement approved by Royal DecreeLaw 8/2019 of March 8, on urgent measures for social protection and against precariousness in the working day (BOE, 2019). Through this Decree-Law, the State takes over the financing of the Social Security contributions of non-professional attention providers of people in dependency situations (this measure was suspended in 2012 due to readjustments of the labour reform).

The development of the SAAD has not been linear and its implementation has been full of changes and delays. In addition, the current configuration based on the implementation of the Law by the Autonomous Communities (hereinafter CC.AA), jeopardizes territorial equality between citizens of different geographic regions. Such a configuration is producing a legislative balkanization and an unequal management of the law what can lead to the proliferation of different subsystems of social welfare in relation to dependency. " Distributing formal attention inequally is not so much related to the different needs that each region may have, but rather to the autonomy of the Autonomous Communities when implementing social policies" (Martínez-Buján, 2014, p. 116).

Even if the system has not been completely ignored, it has been neglected and postponed in its regulation by the public authorities being subordinated to political changes, to the economic cycle and to budgetary restrictions in line with all public administrations and in accordance with other social policies. This fact, together with the role that families continue to play as a social welfare redistributive agent, suggests that the existence of a hybrid model of attention to dependency may be considered (Martínez-López, 2017). In Spain, that is a similar case to that of other social policies in relation to which the Autonomous Communities have broad powers concerning their legislative development.

It is therefore pertinent to assume that the response given by the SAAD to dependency situations is conditioned by our Mediterranean social welfare system, in which the role of the State, the market and the family is very different from that of other models (Arriba and Moreno, 2009; Da Roit, González-Ferrer and Moreno, 2013; Moreno, 2015).

Currently, the existing social protection of people in dependency situations does not cover everybody that is recognized to belong to that collective in those situations, nor does it have neither the foreseen scope nor the foreseen intensity. Many of them are stuck in the so-called $\square$ limbo of dependency $\square$ : people whose degree of protection has been recognized but do not get to the benefits of the System.

\subsection{Social protection in the field of dependency in Romania}

Romania's integration into the European Union in 2007 was the first step on the path to be recognized as a modern State. However, those political, economic and social changes which the country has undergone in a relatively short time are not yet consolidated. Therefore, social policies are still to be developed.

Following the EU membership, the Romanian legislative framework has undergone significant transformations in all fields (social protection, health, education, social 
assistance, etc.). In Romania, other than in Spain, there is no specific legislation on this matter. On the contrary, protection of people in dependency situations is mainly included within that of people with disabilities, as well as, to a lesser extent, within that of elderly people. Almost all public protection resources oriented towards covering dependency situations are addressed at people with disabilities. Therefore, situations of dependency linked to age are relegated to a secondary level if they are not linked to disabilities.

In Law 53/1992 on the Special Protection of People with Disabilities, which was passed in Romania in 1992, they are defined them as those who, need totally or partially, temporarily or permanently special protection due to sensory, physical or mental deficiencies, so that they can achieve social or professional integration into society using their own possibilities (Lege no 53/1992).

In 2002 such definition was revised through Law of 519 of 12 July approving the Government Emergency Ordinance 102/1999 on the Special Protection and Employment of People with Disabilities. However, four years later it was amended again. Currently, people with disabilities are considered to be those who, due to physical, mental or sensory disorders, lack the skills to develop normally daily activities. Consequently, they need to be protected through measures that favour their recovery, integration and social inclusion (Lege no 448/2006). Nevertheless, even in this last definition aspects related to age or situations of dependency that may be caused by an illness are not regarded.

Those Disabilities covered by Law 448/2006 on the Protection and Promotion of the Rights of People with Disabilities are classified according to the following types: physical, visual, hearing, deaf blindness, somatic, mental, psychic, HIV/AIDS, associated disabilities and rare diseases (Lege no 448/2006). The aforementioned classification is different from that developed in Spain in the Royal Legislative Decree 1/2013, of 29 November, approving the Revised Text of the General Law on the Rights of Persons with Disabilities and their Social Inclusion, which classifies persons with disabilities according to the nature of their impairment: physical, mental, intellectual or sensory.

Moreover, according to Law 221 of 11 November 2010, the Romanian Parliament endorsed the Convention on the Rights of People with Disabilities ${ }^{1}$ appointing the National Authority for Persons with Disabilities (hereinafter NAPD) ${ }^{2}$ as that central authority designated to coordinate the implementation of the mentioned Convention (Law no. 221/2010). The NAPD performs functions which are similar to those of the $\mathrm{SAAD}$, despite differences with respect to its scope, content and possibilities.

Recently, the National Strategy "A Barrier-Free Society for People with Disabilities" 2016-2020 and the Operational Plan for the implementation of such strategy (Ministry of Labour and Social Justice, 2016) have been approved. All these legislative changes have led to greater social protection of people in need of long-term assistance

1 After being adopted in New York by the UN General Assembly on 13 December 2006, opened for signature on 30 March 2007 and signed by Romania on 26 September 2007, it became effective on 3 May 2008.

2 In Romanian: Autoritatea Nationala pentru Persoanele cu Dizabilitati. 
(hereinafter, LTC), but still there is lack of consolidation in relation to those activities carried out by the NAPD.

The focus of legislative reforms has been on the social protection system for elderly people, especially for those with no income, no family, no support or insufficient means of living. In Romania, the current trend concerning older people's care is to turn institutional care into home care for it is presumed that older people prefer the latter as it allows them to maintain their independence and social network (government spending on LTC also decreases). However, according to Popa (2010), this assumption of preference may not be correct because home care leads to greater involvement by families or legal guardians, who may be giving up part of their work to provide that care. In addition, as in the case of the Autonomous Communities in Spain, in Romania the aforementioned Law was implemented differently by each responsible County Council (Consiliul Judetean). Consequently, inequalities in both access and care have arisen.

Ghenta (2016) stated that in Romania, as in most European countries, including Spain, it is mostly women who bear social responsibility for care. In addition to that, women in charge of care have very limited knowledge about the existence of formal care services or measures that support those who care for persons in dependency situations.

On the other hand, Ghenta, Matei and Mladen (2015), as remarked in their research on attention services to people in dependency situations, noted that social managers lacked of capacity to develop innovative methods, techniques and practices. In other words, weak management and little interest in developing performance measurement mechanisms are key issues concerning the organisation of the Romanian system of dependency protection.

\section{Dependency situations in Romania and Spain: Data approach}

\subsection{Management of the Dependency Law in Spain}

In Spain, there were 1,663,514 people in recognized dependency situations on April 30th, 2019. This means that 3.6\% of the Spanish population need support to develop basic daily life activities (SAAD, 2019). 29.3\% were recognised with Grade III ${ }^{1}$, 37.5\% had Grade II and 33.2\% had obtained Grade I. In addition, there is a great difference according to gender. As a matter of a fact $64 \%$ are women and $36 \%$ are men.

Of the total number of people who had been assessed, in 1,321,994 of the cases they were entitled to the right to receive economic benefits and/or services. However, only 1,070,100 people received any type of resource, with a significant percentage of people who were found on the "dependency limbo", that is to say, people who, even if their right is recognized, such right is pending until it is possible to be used. Moreover, the percentage of people in a situation of recognised dependency are over 65 years of age

${ }^{1}$ Attention needs increase as the dependency degree rises, with III being the maximum and I the minimum. 
more than $70 \%$. Furthermore, those over 80 exceed 50\% (581,378 people). These data can be seen in Chart 2 as follows.

Table 2. SAAD Statistical data

\begin{tabular}{|l|l|l|l|}
\hline Total population & 46.722 .980 & $100 \%$ \\
\hline Requests & \multirow{2}{*}{1.794 .604} & 1.148 .627 women & \multirow{2}{*}{$3,8 \%$} \\
\cline { 3 - 3 } & & 645.977 men & \\
\hline Resolutions & 1.663 .514 & $3,6 \%$ \\
\hline Resolutions entitled to benefits & 1.321 .994 & $2,3 \%$ \\
\hline Recipients of benefits & \multirow{2}{*}{1.070 .100} & 695.522 women & \multirow{2}{*}{$1,3 \%$} \\
\cline { 3 - 3 } & & 374.578 men & \\
\hline
\end{tabular}

Source: SAAD, 2019. Own elaboration.

Another relevant fact is that there is a feminization of this group since women almost double men. Finally, we can highlight the high number of people who are in the dependency limbo', that is to say, people who have been recognized as potential beneficiaries but who, nevertheless, do not have access to them. Their quantity exceeds 250,000 people according to data registered on April 2019.

To access to LAPAD resources, the process goes through two different stages that belong to a single process: being recognised as a dependent person and having the resolution giving access to a specific economic benefit or service.

Provisions related to dependency attention consist of services and economic benefits with the aim of both promoting personal autonomy and addressing the needs of people with difficulties, so that they manage to carry out the "basic daily life activities"(BDLA). The LAPAD covers following services and economic benefits (Chart 3).

Table 3. Dependency attention benefits in Spain

\begin{tabular}{|c|c|c|}
\hline \multirow{10}{*}{ Services } & \multicolumn{2}{|c|}{ Preventing dependency situations and promoting personal autonomy } \\
\hline & Teleassistance & \\
\hline & \multirow[b]{2}{*}{ Home help } & Attention to home needs \\
\hline & & Personal services care \\
\hline & \multirow{4}{*}{$\begin{array}{l}\text { Day and night } \\
\text { centers }\end{array}$} & Day centres for elderly people \\
\hline & & Day centres for people under the age of 65 \\
\hline & & Specialized attention day centers \\
\hline & & Night centres \\
\hline & \multirow[b]{2}{*}{ Residential care } & Residences for elderly people in dependency situations \\
\hline & & $\begin{array}{l}\text { Centres for people in dependency situations, } \\
\text { according to different types of disability }\end{array}$ \\
\hline \multirow{3}{*}{$\begin{array}{l}\text { Economic } \\
\text { benefits }\end{array}$} & \multicolumn{2}{|c|}{$\begin{array}{l}\text { Economic benefits for care in the family environment and support for non- } \\
\text { professional care providers }\end{array}$} \\
\hline & \multicolumn{2}{|c|}{ Economic benefits linked to the service } \\
\hline & \multicolumn{2}{|c|}{ Economic benefit for personal care } \\
\hline
\end{tabular}

Source: SAAD, 2019. Own elaboration. 
Dependency-related economic benefits and services are designed to promote personal autonomy and to help people with difficulties to perform basic daily living activities addressing attention to their needs. However, article 14.2 of the LAPAD clearly prioritises in-kind benefits over monetary benefits. The intervention of professional care providers is thus recognised as a priority with the aim that the involvement of local services guarantees so the quality of the provided care. In this respect, its purpose is to favour the promotion of personal autonomy, rather than that of home care.

\subsection{Management of the Dependency Law in Romania}

Romania envisages benefits provided to address the needs of LTC for people with disabilities and the elderly, through Law 448/2006 of 6 December on the Protection and Promotion of the Rights of Persons with Disabilities and Law 17/2000 of 6 March on Social Assistance for the Elderly, adapting the services provided to their individual needs (Law no 17/2000).

According to Law 448/2006, people with disabilities are entitled to receive dependency benefits depending on the degree and type of disability while the disability persists. Thus, they may be entitled to home care, partial residential care, residential care and social benefits in cash.

Elderly people, whose age is over the retirement age as established by law, are entitled to obtain dependency services and benefits according to their grade if they are in one of the situations established in Article $3^{1}$ of Law 17/2000 (Law no 17/2000).

In Romania, the ANPD is the body who is in charge of providing statistical data on the evolution of the protection of people with disabilities, but its data are not as detailed as those of the SAAD in Spain. According to ANPD data, on 31 December $2018^{2}$ the total number of disabled people in Romania was 823,956 (3.7\% of the population). It is significant that among them $97.8 \%$ (806,048 individuals) are not institutionalized, what means that they are under the care of their families and/or live in their homes, while $2.2 \%(17,908$ individuals) are in public residential social assistance centres for disabled adults which are coordinated by the Ministry of Labour and Social Justice through the ANPD (ANPD, 2018).

Among the total amount of adults with disabilities, 55\% are between 18-64 years old. Such percentage represents 417,558 individuals. On the other hand, 45\% are over 65 years of age, what accounts 341,397 individuals. Furthermore, women represent $53.0 \%$ of the total number of people with disabilities.

1 Not having family nor receiving the care provided by another person who has a legal obligation to care for you; not having a residence nor the possibility of reaching by one's own means a minimum standard of living; not being able to carry out the basic daily life activities on one's own or needing specialised attention in order to do so; being unable to address one's social and health necessities due to illness, physical or psychological situation.

2 The data presented below refer to this date. 
Table 4. People with disabilities in households and centres in relation to age

\begin{tabular}{|l|l|l|l|}
\hline \multicolumn{1}{|c|}{ People with disabilities } & \multicolumn{1}{|c|}{$\begin{array}{c}\text { People } \\
\text { number }\end{array}$} & Poople (\%) & \multirow{2}{*}{ Potal } \\
\cline { 1 - 2 } Residents in households & 806.048 & $97,8 \%$ & \multirow{2}{*}{$823.9566^{1}$} \\
\hline Residents in centers & 17.908 & $2,2 \%$ & \\
\hline Between 18-64 years old & 417.558 & $55,0 \%$ & \\
\hline Older than 65 years old & 341397 & $45,0 \%$ & \\
\hline
\end{tabular}

Source: ANDP, 2018. Own elaboration.

The number of people with severe disability represents $39 \%$ of the total, with accentuated disability $49.8 \%$ and with medium and mild disability $11.2 \%$ of the total ${ }^{2}$.

The benefits to which elderly people are entitled are stipulated in Article 14 of Law 17/2000 of 6 March on Social Assistance for Elderly People.

Table 5. Type of benefits for dependent elderly people in Romania

\section{Temporary or permanent care at home}

- Social services mainly aimed at attending the person, avoiding their social marginalization and supporting social integration, legal and administrative advice, financial support through payment of current obligations, home care and cleaning services, food preparation.

- Social and health services mainly aimed at providing assistance in personal hygiene, physical and mental rehabilitation, housing conditioning, promotion and participation in economic, social and cultural activities, as well as temporary care in day and night centres or other specialised centres;

- Medical consultations and medical care at home or in health institutions, dental consultations and care, medicament administration, sanitary materials supply

\section{Temporary or permanent care in residential centers for elderly people}

- Social services, consisting of: cleaning services; legal and administrative advice; prevention of social exclusion and support for social integration;

- Social and health services, namely: maintenance and/or rehabilitation of physical or intellectual capacities; occupational therapy programmes; personal hygiene assistance;

- Medical services (specialized medical advice and treatment in institutions or to the bedridden person, if immobilized; nursing care; supply of medications; provision of medical devices; consultations and dental care).

3. Day care centers, centers for elderly people, temporary nursing homes, flats and social housing, etc.

Source: Lege no. 17/2000. Monitorul Oficial, 2000. Own elaboration.

1 Total population of Romania 2018: 19,524,000 people.

2 According to Law 448/2006 on the Protection and Promotion of the rights of people with disabilities, the degrees are: Grade I - mild (mild disability, Grade II - medium (medium disability), Grade III - accentuated (accentuated disability), Grade IV - severe (severe disability). 
Regarding those resources, which are addressed at people with disabilities we will be making a distinction the different kinds of centres and we will also be comparing economic benefits between them. Within the catalogue of centres for people with disabilities we find mainly: residential centres (care and assistance centres, centres for integration through occupational therapy, recovery and rehabilitation centres, centres for preparation for independent living) and non-residential centres (day centres, centres with an occupational profile, neuromotor recovery outpatient centres, mobile equipment, home services, recovery and social integration centres, etc.).

As for economic benefits for people with disabilities, the Article 58 of Law 448/2006 establishes that people with disabilities may receive monthly subsidies depending on their disability degree. Furthermore, severely disabled people may benefit from additional grants, such as: an economic loan by virtue of a transfer from the budget for the purchase of a vehicle or the adaptation of housing to their needs, as contemplated in the Article 27 of the aforementioned Law.

It is relevant mentioning that those social provisions for Romanian people in dependency situations contemplated in Law 17/2000 on the Protection of Elderly People, contrary to what happens in Spain, have the nature of services and that, only to meet certain current payments, economic support might be agreed, assuming that support is finalist and does not have to undergo monitoring nor evaluation. In the next Chart 6, economic benefits and services which exist in Romania as provided for in Law 448/2006 and Law 17/2000, are specified.

Table 6. Economic benefits and Services for dependency attention in Romania

\begin{tabular}{|c|c|c|c|}
\hline \multirow{5}{*}{ Services } & \multicolumn{2}{|l|}{ Law 448/2006 } & Law $17 / 2000$ \\
\hline & \multicolumn{2}{|c|}{ Visiting assistance } & \multirow{4}{*}{$\begin{array}{l}\text { Care at Home } \\
\text { Care in Residential } \\
\text { centers for the elderly } \\
\text { Day care centers; centers } \\
\text { for elderly people; } \\
\text { Temporary nursing } \\
\text { homes; Social care } \\
\text { apartments and houses }\end{array}$} \\
\hline & \multirow{3}{*}{$\begin{array}{l}\text { Residential } \\
\text { assistance (full } \\
\text { and/or partial) }\end{array}$} & $\begin{array}{l}\text { Recovery and rehabilitation } \\
\text { centres }\end{array}$ & \\
\hline & & $\begin{array}{l}\text { Integration/occupational } \\
\text { therapy centres }\end{array}$ & \\
\hline & & $\begin{array}{l}\text { Centers preparing to live } \\
\text { independently }\end{array}$ & \\
\hline \multirow{3}{*}{ Benefits } & \multicolumn{2}{|c|}{$\begin{array}{l}\text { Economic compensation according to the } \\
\text { disability degree }\end{array}$} & $\begin{array}{l}\text { Economic benefit } \\
\text { according to dependency } \\
\text { degree }\end{array}$ \\
\hline & \multicolumn{2}{|c|}{ Economic benefit to purchase vehicles } & Finalist economic \\
\hline & \multicolumn{2}{|c|}{ Economic benefit to adapt housing } & $\begin{array}{l}\text { monitoring nor } \\
\text { evaluation) }\end{array}$ \\
\hline
\end{tabular}

Source: Monitorul Oficial 2000, 2006. Own elaboration.

With respect to the need for care at home, Romanian legislation provides in the article 13 of Law 17/2000 that the Local Administration (Local Councils) may guarantee the care of people in dependency situations at home by hiring people as caregivers, whose contract is done for hours, half or full time and during the period when the dependent 
person needs care. A remarkable fact is that it is not an obligation, but a possibility for the town councils. It represents a declaration of intentions and may be managed arbitrary by each local entity. In Spain this service is developed through the home help assistant, a function that is included in the Law but is poorly developed.

In that article of the Act it is mentioned that husbands/wives or relatives caring for the dependent person may benefit from a working day reduction of half a day; the other half day being economically remunerated from the local administration budget for an amount equivalent to the salary of a personal assistant. During this care, husbands/ wives or family carers are having full-time registration with the Social Security.

\section{Comparative analysis of social protection levels in Spain and Romania}

There are significant differences between Spain and Romania in relation to their social protection systems. This fact conditions the response given by each country both to the challenge of LTC and the protection of people in dependency situations. In the next Chart 7, we can see the most significant differences of each model.

Table 7. Analysis of dependency attention systems in Spain and Romania

\begin{tabular}{|l|l|l|l|}
\hline \multicolumn{1}{|c|}{ Dimension } & Analysis unit & \multicolumn{1}{c|}{ Spain } & \multicolumn{1}{c|}{ Romania } \\
\hline $\begin{array}{l}\text { Documentary } \\
\text { dimension of } \\
\text { social } \\
\text { protection } \\
\text { models }\end{array}$ & SW features & $\begin{array}{l}\text { Familistic model of } \\
\text { social protection with } \\
\text { social democratic } \\
\text { features: hybrid model of } \\
\text { social protection }\end{array}$ & $\begin{array}{l}\text { Mixed model (with } \\
\text { different nuances of the } \\
\text { "classic" models of welfare) } \\
\text { with a strong liberal } \\
\text { character and a modest role } \\
\text { for social policies. }\end{array}$ \\
\hline & $\begin{array}{l}\text { Authorship } \\
\text { legislative }\end{array}$ & $\begin{array}{l}\text { Mixed. The State and the } \\
\text { Autonomous } \\
\text { Communities regulate } \\
\text { within their sphere of } \\
\text { competencies. }\end{array}$ & $\begin{array}{l}\text { Centralized. The State } \\
\text { regulates general rules. }\end{array}$ \\
\cline { 2 - 5 } & $\begin{array}{l}\text { Concept of } \\
\text { dependency } \\
\text { protection } \\
\text { dimension }\end{array}$ & $\begin{array}{l}\text { Recognized as a } \\
\text { universal right that } \\
\text { favours the development } \\
\text { of social citizenship }\end{array}$ & $\begin{array}{l}\text { Bonded to the elderly and } \\
\text { subordinated its exercise to } \\
\text { the possibilities of local } \\
\text { administration }\end{array}$ \\
\cline { 2 - 5 } & $\begin{array}{l}\text { Normative } \\
\text { development }\end{array}$ & $\begin{array}{l}\text { It has specific regulations } \\
\text { in relation to } \\
\text { dependency attention }\end{array}$ & $\begin{array}{l}\text { It has not specific } \\
\text { regulations, but covers the } \\
\text { needs of this group with } \\
\text { other laws. }\end{array}$ \\
\cline { 2 - 5 } & $\begin{array}{l}\text { Dependency } \\
\text { degrees }\end{array}$ & $\begin{array}{l}\text { There is a differentiated } \\
\text { classification for people } \\
\text { with disabilities and in } \\
\text { dependency situations. }\end{array}$ \\
\cline { 2 - 5 } & $\begin{array}{l}\text { There are three levels } \\
\text { attention } \\
\text { benefits }\end{array}$ & $\begin{array}{l}\text { Catalogue of services } \\
\text { and economic benefits } \\
\text { covering all situations }\end{array}$ & $\begin{array}{l}\text { There are benefits and } \\
\text { services according to the } \\
\text { access group: elderly or }\end{array}$ \\
\hline
\end{tabular}




\begin{tabular}{|c|c|c|c|}
\hline Dimension & Analysis unit & Spain & Romania \\
\hline & & & $\begin{array}{l}\text { disabled people. } \\
\text { The possibilities of } \\
\text { benefiting from them } \\
\text { depend on personal and } \\
\text { family factors. }\end{array}$ \\
\hline \multirow{3}{*}{$\begin{array}{l}\text { Dimension of } \\
\text { social } \\
\text { protection for } \\
\text { people in } \\
\text { dependency } \\
\text { situations }\end{array}$} & $\begin{array}{l}\text { Coverage } \\
\text { management } \\
\text { and attention } \\
\text { for people in } \\
\text { dependency } \\
\text { situations }\end{array}$ & $\begin{array}{l}\text { The intensity of social } \\
\text { protection depends on } \\
\text { the dependency degree }\end{array}$ & $\begin{array}{l}\text { Depends on whether the } \\
\text { person is classified as } \\
\text { disabled or older }\end{array}$ \\
\hline & $\begin{array}{l}\text { Responsibility } \\
\text { in public } \\
\text { management }\end{array}$ & $\begin{array}{l}\text { Decentralized: State, } \\
\text { Autonomous } \\
\text { Communities, being the } \\
\text { responsibility of public } \\
\text { provision. }\end{array}$ & $\begin{array}{l}\text { The State and } \\
\text { Municipalities, on the one } \\
\text { hand, and the third sector, } \\
\text { on the other, participate in } \\
\text { the attention management } \\
\text { with differentiated } \\
\text { competencies. }\end{array}$ \\
\hline & $\begin{array}{l}\text { Informal } \\
\text { caregiver } \\
\text { support }\end{array}$ & $\begin{array}{l}\text { It is included in the } \\
\text { Dependency Law }\end{array}$ & $\begin{array}{l}\text { Elderly depend on the } \\
\text { Administration and } \\
\text { resemble the figure of } \\
\text { home assistant. }\end{array}$ \\
\hline
\end{tabular}

Source: Theoretical, legislative and management analysis. Own elaboration.

As for the first of the variables, the documentary analysis of social protection models, it can be observed that Spain maintains a hybrid dependency attention model. Even though the Law has social-democratic nuances, the outstanding role of families in social welfare relegates the social responsibility of the State to the second level. As for the social protection model implemented in Romania it is characterized for being "in progress". The social response to people in dependency situations is limited in as much as it has characteristics of different models of social protection.

If we compare the legislative dimension, we find that the main difference lays on the central question whether or not a specific law for this group exists. In the case of Spain, in 2006 the LAPAD was passed and thus the SAAD was created as vertebral structure of attention to dependency. On the contrary, in Romania there is a patchwork of laws aimed at addressing the needs of elderly people and those with disabilities, but there is no unification concerning social protection of people in dependency situations. As a consequence of this, an administrative and territorial structure that makes it possible to guarantee attention to people who need LTC is lacking.

Finally, social protection to people in dependency situations with regard to both countries is conditioned by the two previous dimensions. Spain has a greater organisation of benefits and services for this collective, but the role performed by families concerning social welfare determines the configuration of the universal right. Sometimes, the capacity of the State is consciously estimated and the possibility of reductions in social rights belong to the collective imaginary because there will always be a family member, usually incarnated in the figure of a woman, who will be 
responsible for care. On the other hand, social protection offered to Romanian population is determined by the capacity of its municipalities to face LTC needs. The population has resources and state benefits but the coverage is much lower compared to Spain. It can be seen how Romania's response is conditioned by its social protection model "in progress" and the absence of clear laws that articulate a global response to all the collective of citizens in dependency situations.

\section{Discussion and conclusions}

Spain and Romania, in comparison both with the Central European and Nordic countries, have a short history in relation to the WS for it has been created recently. The different development of their social policy has been marked to a great extent by their specific historical and political context. In both countries attention to people in dependency situations is a present and future challenge given population ageing and the increase in life expectancy

When attempting to classify social welfare systems of attention to dependency, we observe that it is difficult to classify the Romanian model, which presents characteristics that do not allow it to be classified according to a single model due to its continuous transformation and to the fact that it is still in the process of development. As for Spain, its model is part of the familistic WS model, where the family, particularly in the policy of attention to dependency, has a primary role in the provision of social welfare of its members. Such model has been based on women's informal work, what has important gender implications. This is for example the case of women who face higher opportunity costs in order to get employment in the formal labour market and to achieve economic independence.

It has been observed in this analysis that, in relation to dependency attention, the Spanish social protection model and the Romanian one are clearly different. Such differences are originated due to their social welfare models and their development of a legal framework for dependency attention.

In Romania, other than in Spain, there is not any single legal norm that provides for the attention of people in dependency situations. Nevertheless, such legislation contemplates a wide range of situations to be protected and offers different social benefits adapted to the needs of each person, who is in such a situation. Thus, dependency benefits protect those people with disabilities who are entitled to receive them depending on the type of disability; and also support elder people who have reached the normal retirement age depending on the dependency degree in both cases. On the other hand, in Romania there is a complex legislative tangle where legal changes are constant. In addition to this, many social agents participate in public social coverage, what makes coordination and planning difficult.

In Spain, according to the LAPAD protection of people in dependency situations, is considered as a subjective right and the State accepts this responsibility. However, since the approval of the LAPAD, regulatory changes that have affected this system of social protection have been continuous and many researchers recognise that is may be considered to be a hidden derogation of the law. 
No matter how each country has developed their particular normative framework, fact is that both, Spain and Romania according to their own laws, face the challenge of addressing LTC needs, at an equality, quality and guarantee-based level. The Spanish model clearly establishes the different benefits of the SAAD in accordance with the assessment of the dependency degree, what favours the transparency of the process, the equality between the different citizens, as well as enhancing coordination of public actions. On the other hand, in the Romanian model, which is characterised by the inexistence of specific protection for people in dependency situations, there is lack of suitable coordination between the different public administrations. In some cases, their measures are sometimes different depending on each local entity, so that neither coverage nor access to social benefits is guaranteed on equal terms.

Social policy in relation to dependency may cause an increase in social cost, but, thanks to its development, society as a whole will be compensated for such cost through fiscal returns, greater employment in the social and health sector, coherence of policies in relation to the citizenship social needs and, last but not least, through a society where more fairness and equality have been pursued.

\section{References}

ANPD (2018). Date statistice. Available on http://anpd.gov.ro/web/wp-content/uploads/ 2019/03/BULETIN-STATISTIC-ANPD-TRIM-IV-2018.pdf

Arriba, A., y Moreno, F. J. (Eds.) (2009). El tratamiento de la dependencia en los regímenes de bienestar europeos contemporáneos. Instituto de Mayores y Servicios Sociales, Madrid, España.

BOE (2019). Real Decreto-ley 8/2019, de 8 de marzo, de medidas ungentes de protección social y de lucha contra la precariedad laboral en la jornada de trabajo. Recuperado de https://www.boe.es/ buscar/doc.php?id=BOE-A-2019-3481

Da Roit, B., González-Ferrer, A., y Moreno, F. J. (2013). The new risk of depedency in old age and (missed) employment opportunities: The Southern Europe model in a comparative perspective. En J. Troisi, y H. J. V. Kondratowitz (Eds.), Ageing in the Mediterranean (p. 151172). Bristol, Reino Unido: Policy Press.

Del Pino, E., y Lara, M. (2013). Los Estados de bienestar en la encrucijada. Tecnos, Madrid, España.

Del Pino, E., y Rubio, M. J. (Dir.). (2016). Los Estados de Bienestar en la encrucijada. Políticas sociales en perspectiva comparada. Tecnos, Madrid, España.

Esping-Andersen, G. (1990). Los tres mundos del estado de bienestar. Alfons el Magnánim, Valencia, España.

Esping-Andersen, G. (2000). Fundamentos sociales de las economias postindustriales. Ariel, Barcelona, España.

Eurostat. (2016a). Tasas de población. Available on https://ec.europa.eu/eurostat/statisticsexplained/index.php?title $=$ Population_structure_and_ageing/es

Eurostat. (2016b). Esperanza de vida al nacimiento. Available on https://ec.europa.eu/eurostat/ statisticsexplained/images/0/0c/Life_expectancy_at_birth\%2C_19802016_\%28years\%29.png

Eurostat. (2018). PIB por habitante en estándar de poder adquisitivo. Available on https://ec.europa.eu/ eurostat $/ \mathrm{tgm} / \mathrm{table} \cdot \mathrm{do} ? \mathrm{tab}=$ table\&init $=1 \&$ plugin $=1 \&$ language $=$ en\&pcode $=$ tec 001144

Fenger, M. (2007). Welfare regimes in Central and Eastern Europe: Incorporating postcommunist countries in a welfare a. Contemporary Issues and Ideas in Social Sciences, s.d. 
Available on http://www.learneurope.eu/files/9913/7483/4204/Welfare_regimes_in_ Central_and_Eastern_Europe.pdf

Ghenta, M. (2016). Ingrijirea persoanelos varstnice in cadrul familiei-negocierea rolului de ingrijitor. In A. Matei, M. Gheanta, D. Badoi y B. Sanduleasa, Roluri de gen şi implicaţii în realizarea echilibrului între viața profesională și viața de familia (pp. 131-186). Editura Universitara Bucuresti, Bucharest, Romania. Available on https://www.researchgate.net/publication/ 301516056_Ingriijirea_persoanelor_varstnice_in_cadrul_familiei_negocierea_rolului_de_in grijitorFamily_care_of_elderly_negotiating_the_role_of_caregiver

Ghenta, M., Matei, A., y Mladen, L. (2015). Performance measurement in social care services for older people. Revista Romaneasca pentru Educatie Multidimensionala, 7(2), 97-109. doi: 10.18662/rrem/2015.0702.09

Legea nr 17/2000 (2000). Privind asistenta sociala a persoanelor varstnice. Monitorul Oficial. $N^{0} 104$ (04/03/00). Available on http://www.monitoruljuridic.ro/act/lege-nr-17-din-6-martie2000-privind-asistenta-sociala-a-persoanelor-varstnice-emitent-parlamentul-publicat-n21309.html

Legea nr 221/2010 (2010). Pentru ratificarea Conventiei privind drepturile persoanelor cu dirabilitati, adoptata la New York de Adunarea Generala a Organizatiei Natiunilor Unite la 13 decembrie 2006, deschisa spre semnare la 30 martie 2007 si semnata de Romania la 26 septembrie 2007. Monitorul Oficial. $N^{o} 792$ (26/11/10). Available on http://www.monitoruljuridic.ro/act/lege-nr-221din-11-noiembrie-2010-pentru-ratificarea-conventiei-privind-drepturile-persoanelor-cu-

dizabilitati-adoptata-la-new-york-de-adunarea-generala-a-organizatiei-natiunilor-unite-la-13decembrie-123949.html

Legea nr 448/2006 (2006). Privind protectia si promovarea drepturilor persoanelor cu handicap. Monitorul Oficial. $N^{o} 1.106$ (18/12/06). Available on http://www.monitoruljuridic.ro/act/lege-nr448-din-6-decembrie-2006-privind-protectia-si-promovarea-drepturilor-persoanelor-cuhandicap-emitent-parlamentul-publicat-n-77815.html

Legea nr 519/2002 (2002). Pentru aprobarea Ordonantei de ungenta a Guvernului nr. 102/1999 privind protectia speciala si incadrarea in munca a persoanelor cu handicap. Monitorul Oficial. $N^{o} 555$ (29/07/02). Available on http://www.monitoruljuridic.ro/act/lege-nr-519-din-12-iulie2002-pentru-aprobarea-ordonantei-de-urgenta-a-guvernului-nr-102-1999-privind-protectiaspeciala-si-incadrarea-in-munca-a-persoanelor-cu-handicap-37685.html

Legea $\mathrm{nr}$ 53/1992 (1992). Privind protectia speciala a persoanelor handicapate. Monitor Oficial. No 119 (4/6/92). Available on http://www.monitoruljuridic.ro/act/lege-nr-53-din-1-iunie-1992privind-protectia-speciala-a-persoanelor-handicapate-emitent-parlamentul-romanieipublicat-n-2266.html

Martínez-Buján, R. (2011). La reorganización de los cuidados familiares en un contexto de migración internacional. Cuadernos de relaciones laborales, 29(1), 99-123.

Martínez-Buján, R. (2014). Los modelos territoriales de organización social del cuidado a personas mayores en los hogares. REIS, (145), 99-126.

Martínez-López, J. A. (2017). El modelo híbrido de atención a las personas en situación de dependencia en España: una década de cambios normativos y ajustes presupuestarios. Revista del CLAD Reforma y Democracia, 68, 135-168.

Martínez-López, J. A., Frutos, L., y Solano, J. C. (2017). Los usos de las prestaciones económicas de la dependencia en el municipio de Murcia. Un estudio de caso. Revista Española de Sociología, 26(3 Supl.), 97-113.

Neesham, C., y Tache, I. (2010). The emerging East European social model: A comparative overview. International Advances in Economic Research, 12(3), 1-15.

Popa, D. (2010). Long term care in Romania country report (CASE Network Studies \& Analyses $N^{\circ}$ 419/2010). Available on http://www.case-research.eu/files/?id_plik=4337 
22 Social protection for people in dependency situations in Spain and Romania

SAAD. (2019). Información estadística del Sistema para la Autonomía y Atención a la Dependencia. Available on http://www.imserso.es/imserso_01/documentacion/estadisticas/info_d/estadisticas/est_i nf/datos_estadisticos_saad/index.htm

Salido, O., y Moreno, L. (2007). Bienestar y políticas familiares en España. Politica y Sociedad, 2007, 44(2), 101-114.

Toussaint, E. (2010). Una mirada al retrovisor. El neoliberalismo desde sus origenes hasta la actualidad. Icaria, Barcelona, España.

Zalakain, J. (2017). Atención a la dependencia en la UE: Modelos, tendencias y retos. Revista de derecho social y empresa, (8). 